[Note]

\title{
The Analysis of Cyanobacterial Neurotoxins by High-Performance Liquid Chromatography-Mass Spectrometry
}

\author{
Jong-Mun Jung ${ }^{1,2 *}$, You-Jung Lee ${ }^{1,2}$, Hong-Ki Park ${ }^{2}$, Eun-Young Jung ${ }^{2}$ and Gea-Jae Joo ${ }^{1}$ \\ ${ }^{1}$ Department of Biology, Pusan National University, Busan 609-735 and \\ ${ }^{2}$ Busan Water Quality Institute, Busan Waterworks HQ, Kyoungnam 621-813, Korea
}

\begin{abstract}
Cyanobacteria were dominant from June to September in the Nakdong River and the Hoedong Reservoir. Microcystis aeruginosa was dominant from June to September; Anabaena flos-aquae from June to August and Aphanizomenon flos-aquae from July to August. Cyanobacterial neurotoxins, Anatoxin-a and saxitoxin were analyzed by electrospray ionization-mass spectrometry with strains of Aphanizomenon flos-aquae NIES-81 and Anabaena flosaquae NIER-10002. Anatoxin-a was not detected from the cultured Anabaena flos-aquae nor from the wild samples. Low levels of saxitoxin were detected in the cultured Aphanizomenon flos-aquae; however, those of field samples were below the detection limit.
\end{abstract}

Key Words: anatoxin-a, Aphanizomenon flos-aquae, cyanobacterial toxins, LC-MS, saxitoxin

\section{INTRODUCTION}

Recently annual cyanobacterial blooms occurred during summer and early fall in the Nakdong RiverReservoir system (Ha 1999). Cyanobacteria, especially members of the genera Microcystis, Anabaena, Aphanizomenon and Oscillatoria are common and potentially harmful in the freshwater environments (Falconer 1993). Some genera of cyanobacteria are known to produce three types of intracellular toxins: cyclic hepatotoxins (microcystins, nodularin), alkaloid neurotoxins (anatoxins, saxitoxin, neosaxitoxin) and alkaloid cytotoxin (cylindrospermopsin) (Carmichael 1992; Harada et al. 1994; Falconer 1999).

Anatoxin-a (ANTX-a) and saxitoxins (STXs) are neurotoxin alkaloids produced by a number of blue-green algae (cyanobacteria) including Anabaena, Aphanizomenon and Oscillatoria. ANTX-a is a potent agonist for nicotinic acetylcholine receptor, acts as a postsynaptic depolarizing neuromuscular blocking agent and has been associated with Anabaena flos-aquae, Anabaena spiroides, Anabaena circinalis, and Oscillatoria. Anabaena circinalis blooms in Australia have recently shown to produce paralytic shellfish poisons (Baker and Humpage 1994;

*Corresponding author (jmjung4356@empal.com)
Steffensen 1994).

STXs are carbamate alkaloids and more than 20 chemical analogues have been characterized (Oshima 1995) and 16 have been identified in freshwater cyanobacteria (Sivonen and Jones 1999). Especially, saxitoxin and neosaxitoxin (neoSTX) were shown to be the major neurotoxins present in Aphanizomenon flos-aquae (Mahmood and Carmichael 1986). The toxin was described as a "very fast death factor (VFDF)" since the toxin acts in a few minutes, with very few deaths occurring after $5 \mathrm{~min}$ (Alam et al. 1973). These toxins present acute hazards to human and animal health and are responsible for isolated and sporadic animal fatalities; in mammals, fish and birds. Monitoring the levels of these toxins is important in the management of reservoir and drinking waters (Namera et al. 2002).

Preparative separation of the ANTX-a and STX has been accomplished with a variety of techniques, including ion-exchange chromatography (Jaime et al. 2001), thin-layer chromatography (Ikawa et al. 1982), electrophoresis (Alam et al. 1973) and gas chromatographymass spectrometry (Zotou and Jefferies 1993). This study was to applied to develop a sensitive, simple, reliable and highly selective method for the determination of optimized LC-MS method for anatoxin-a and saxitoxin of freshwater cyanobacterial toxins in the municipal water management. 


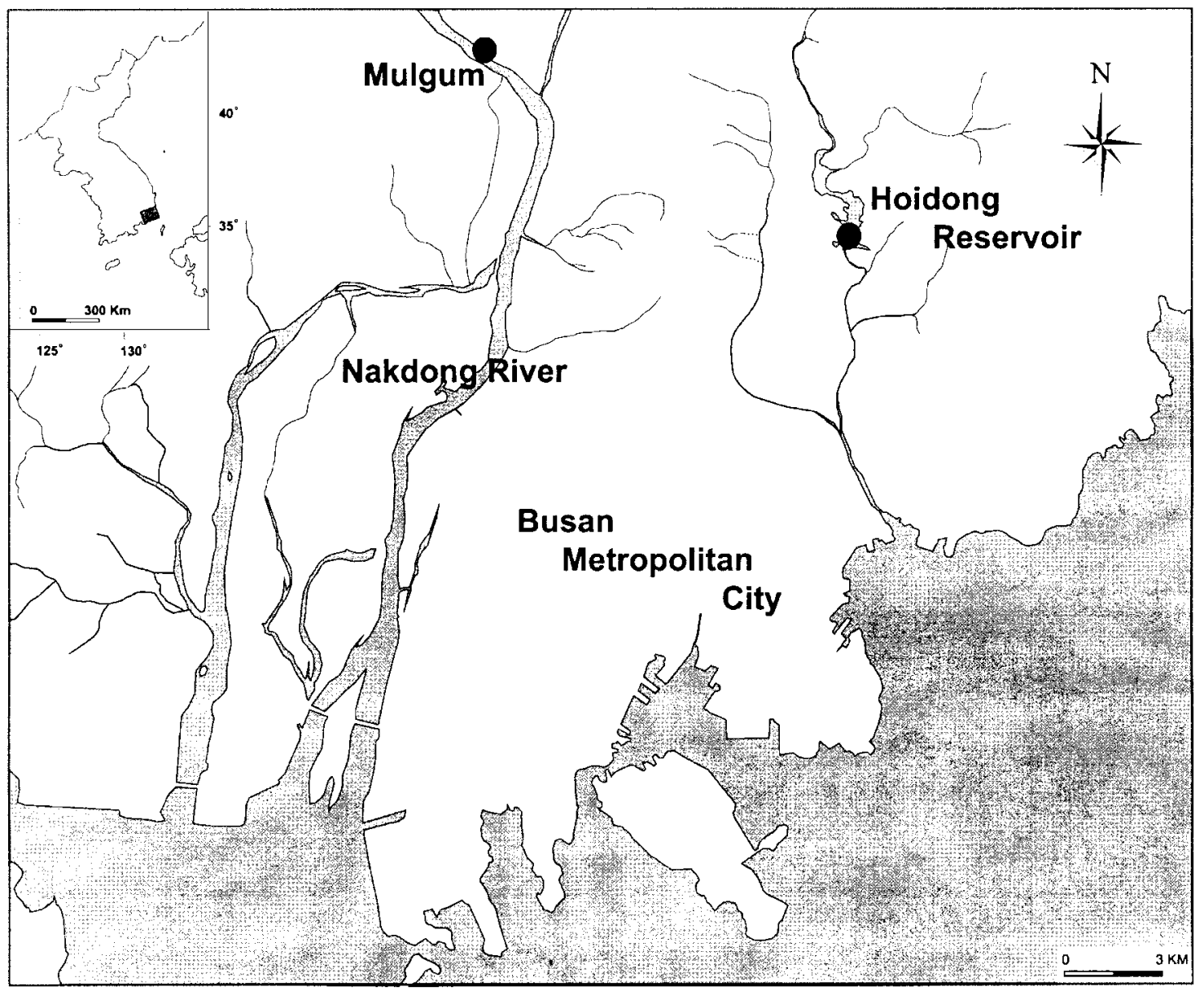

Fig. 1. Map and location of the study sites in Mulgum and Hoedong Reservoir.

\section{MATERIALS AND METHODS}

\section{Collection of samples}

Cyanobacterial samples for toxin analysis were collected by plankton net (20 $\mu \mathrm{m}$ mesh) at Mulgum in July 1999 and at Hoedong Reservoir in January 2000 (Fig. 1). The samples were stored in a cooler for transport to the laboratory, cleaned of debris, rinsed with distilled water, lyophilized (Samwon, SFDSF12, Korea), and stored at $-20^{\circ} \mathrm{C}$ until screened for toxicity by mouse bioassay and analysis for toxin content by LC-MS. The concentrations of chlorophyll $a$ as phytoplankton biomass were monitored spectrophotometrically (Wetzel and Likens 1991; Ha 1999).

\section{Cultivation of cyanobacterial samples}

Strains of Anabaena flos-aquae NIER-10002 (National Institute for Environmental Research, Korea) and Aphanizomenon flos-aquae NIES-81 (National Institute for Environmental Studies, Japan) were used in this study. The culture was maintained in the CB medium buffered with TAPS (N-tris[Hydroxymethyl]-3-aminopropanesulfonic acid). The $0.5 \mathrm{ml}$ of sample was inoculated to $100 \mathrm{ml}$ CB medium in $250 \mathrm{ml}$ glass Erlenmeyer flask and its initial cell density was about 105 cells $\cdot \mathrm{ml}^{-1}$. The cultures were maintained at $25 \pm 1^{\circ} \mathrm{C}$, under 1500 lux illumination and 12L:12D photoperiod. Cultures were harvested about 20 days after inoculation for analysis.

Cell densities were estimated by an inverted microscope (Axiovert 135M, Zeiss, Germany) with SedgewickRafter Chamber. The ranges of densities were 1.0-2.0 $\times$ $10^{7}$ cells $\cdot \mathrm{ml}^{-1}$ for Anabaena flos-aquae NIER-10002 and 1.5$2.5 \times 10^{7}$ cells $\cdot \mathrm{ml}^{-1}$ for Aphanizomenon flos-aquae NIES-81.

\section{Chemicals and standards}

All solvents and chemicals were HPLC and analytical grade; acetonitrile (Merck, Germany) and heptafluorobutyric acid (analytical grade, Aldrich A16419-4. USA). Water was purified with a Milli-Q Ultra pure Water System (Millipore, USA). Standard for ANTX-a from ICN (No. 159873, USA) and STX from Sigma (S1417, USA). 


\section{Extraction of samples for ANTX-a}

Aliquiots of HPLC grade water $(100 \mathrm{ml})$ were spiked at $1.0 \mu \mathrm{g} \cdot \mathrm{l}^{-1}$ and $3.0 \mu \mathrm{g} \cdot l^{-1}$ with ANTX-a. Aliquiots of field sample water taken from Nakdong River $(100 \mathrm{ml})$ were spiked at $1.0 \mu \mathrm{g} \cdot \mathrm{l}^{-1}$ with ANTX-a. Solid-phase extraction cartridges (100 mg sorbent mass: OASIS Waters, UK) were preconditioned with methanol $(10 \mathrm{ml})$ followed by HPLC grade water $(20 \mathrm{ml})$. The samples were then applied to the cartridges and allowed to percolate through the sorbent bed gravity. The cartridges were dried under vacuum and the analyte eluted into a clean glass vial with methanol containing $0.1 \% \mathrm{v} / \mathrm{v}$ trifluoroacetic acid $(2 \mathrm{ml})$. The extracts were evaporated at $40^{\circ} \mathrm{C}$ under nitrogen. The samples were reconstituted in $1 \mathrm{ml}$ of $10 \%$ methanol, capped and stored prior to analysis (Fig. 2).

\section{Extraction of samples for STX analysis}

The lyophilized Aphanizomenon flos-aquae samples (1.0 g) were extracted with $5 \%$ acetic acid at $50 \mathrm{ml} \cdot \mathrm{g}^{-1}$ of materials by sonicating $(20 \mathrm{KHz}, 180 \mathrm{~W})$ for 30 seconds (Fig. 2). The mixture was stirred for 24 hour at room temperature and centrifuged at $20,000 \times \mathrm{g}$ for $30 \mathrm{~min}$ at $4{ }^{\circ} \mathrm{C}$. The suspensions were filtered through a filter (GF/C Millipore, USA) to remove cell debris. Filters were washed with $5 \%$ acetic acid, and samples were passed through a ODS cartridges (Sep-Pak $\mathrm{C}_{18}$, Waters, USA) which had been washed and pre-equilibrated with $10 \mathrm{ml}$ each of methanol and distilled water.

Toxins were eluted with 100\% methanol (LiChrosolv UN 1230, HPLC grade Merck, Germany). The eluate was evaporated under reduced pressure and then the residue was dissolved in $1.0 \mathrm{ml}$ of $5 \%$ methanol. Before HPLC analysis, each sample was filtered through a ultrafiltration membrane with 10,000 dalton cut-off (Ultrafree-MC, Millipore, USA) and centrifuged at 5,000 $\mathrm{g}$ for $15 \mathrm{~min}$. The concentrated extract was the transferred to a $300 \mu l$ HPLC vial and stored prior to analysis (Fig. 2).

\section{Bioassay}

Mouse bioassays were performed according to the Association of Official Analytical Chemists method (AOAC 1995) for paralytic shellfish poisons (PSPs) with using male mice 16-21 g (Balb-C). Mice were injected intraperitoneally with $1.0 \mathrm{ml}$ extracts obtained from the lyophilized material extracted with $0.1 \mathrm{~N} \mathrm{HCl}$. Given sufficient amount of sample, tree mice were injected 0.25 $\mathrm{mg}, 0.5 \mathrm{mg}$ and $1.0 \mathrm{~g}$ material, respectively. Symptoms of poisoning and survival times were recorded. Toxicities

\begin{tabular}{|c|c|}
\hline $\begin{array}{l}\text { lyophilized cells } 1.0 \mathrm{~g} \\
\text { (for ANTX-a ) }\end{array}$ & $\begin{array}{l}\text { lyophilized cells } 1.0 \mathrm{~g} \\
\text { (for STX) }\end{array}$ \\
\hline $\begin{array}{l}\leftarrow \text { extracted with } 0.05 \mathrm{M} \mathrm{AcOH} \\
\leftarrow \text { tree times } \\
\leftarrow \text { centrifuged } 10,000 \mathrm{rpm}, 1 \mathrm{hr}, 4^{\circ} \mathrm{C}\end{array}$ & $\begin{array}{l}\leftarrow \text { extracted with } 3 \% \mathrm{AcOH} \\
\leftarrow \text { tree times } \\
\leftarrow \text { centrifuged } 20,000 \times \mathrm{g}, 30 \mathrm{~min}, 4^{\circ} \mathrm{C}\end{array}$ \\
\hline \multicolumn{2}{|c|}{ supernatant } \\
\hline $\begin{array}{l}- \text { pass } \mathrm{C}_{18} \text { cartridge } \\
\leftarrow \text { air dry (overnight) } \\
\leftarrow \text { washed with water and } 10 \% \mathrm{MeOH} \\
\leftarrow \text { elute } 100 \% \mathrm{MeOH} \\
\leftarrow \text { evaporated dry } \\
\leftarrow \text { elute } 5 \% \mathrm{AcOH} 1.0 \mathrm{~m} /\end{array}$ & $\begin{array}{l}\leftarrow \text { pass } \mathrm{ODS} \mathrm{C}_{18} \text { cartridge } \\
\leftarrow \text { air dry (overnight) } \\
\leftarrow \text { elute } 100 \% \mathrm{MeOH} \\
\leftarrow \text { evaporated dry } \\
\leftarrow \text { elute } 5 \% \mathrm{AcOH} 1.0 \mathrm{~m} / \\
\leftarrow 10,000 \text { dalton cut-off }\end{array}$ \\
\hline \multicolumn{2}{|c|}{ LC-MS injection $(2.0 \mu /)$} \\
\hline
\end{tabular}

Fig. 2. The analysis procedure of ANTX-a and STXs in cyanobacterial cells.

Table 1. HPLC gradient conditions for anatoxin-a

\begin{tabular}{ccc}
\hline time (min) & acetonitrile $(0.1 \%$ TFA) & water $(0.1 \%$ TFA $)$ \\
\hline 0.00 & 2 & 98 \\
8.00 & 20 & 80 \\
8.01 & 50 & 50 \\
10.00 & 50 & 50 \\
10.01 & 2 & 98 \\
\hline
\end{tabular}

were expressed by mouse unit (MU), where one MU was defined as the amount of toxins required to kill a mouse of $20 \mathrm{~g}$ body weight in $15 \mathrm{~min}$ following i.p. injection. Survivals over 20 hours were determined to be nontoxic.

\section{LC-MS analysis of anatoxin-a}

LC-MS was used with electrospray ionization (ESI). The $150 \times 2.1 \mathrm{~mm}$ XTera $\mathrm{C}_{18}$ column $(3.5 \mu \mathrm{m}$ particle size, maintained at $30^{\circ} \mathrm{C}$, Waters, USA) was used. The optimization of drying gas and nebulizer gas were done to introduce ANTX-a standard solution at $0.2 \mathrm{ml} \cdot \mathrm{min}^{-1}$. The $2.0 \mu l$ of sample was injected and a gradient elution was performed with using water and acetonitrile, both containing $0.1 \%$ trifluoroacetic acd (TFA) (Table 1 ).

\section{LC-MS analysis of saxitoxin}

The LC-MS system was consisted of a Waters ZQ micromass, Allience 2695 (Waters, USA) and a reversedphase XTerra MS $\mathrm{C}_{18}$ column $(3.5 \mu \mathrm{m}, 150 \times 2.1 \mathrm{~mm}$ i.d., Waters, USA). Chromatographic conditions were similar 
to those described by Lagos (1999) using heptafluorobutyric acid as an ion pair reagent. The mobile phases consisted of aqueous $10 \mathrm{mM}$ heptafluorobutylic acid and acetonitrile in 80:20 for STX were used isocratically at a flow rate of $0.2 \mathrm{ml} \cdot \mathrm{min}^{-1}$. A ZQ micromass spectrometer equipped with an atmospheric pressure ion source and an electrospray ionization (ESI) interface (Waters, USA) was employed for detection. ESI was effected by a spray voltage of $+3.0 \mathrm{kV}$ and heated capillary temperature was maintained at $250^{\circ} \mathrm{C}$. High purity nitrogen served UHPLCMS nitrogen generater (NITROX, Korea) at an operating pressure of 80 psi. Full scan spectra were acquired in the positive ion peak continue mode over the mass ranges of $m / z$ 200-500 for STX. Instrumental control, data acquisition and data processing were performed with an Empower soft program on COMPAQ (P720, USA) computer.

\section{RESULTS AND DISCUSSION}

\section{Cyanobacterial bloom formation in the lower Nakdong River and Hoedong Reservoir}

Cyanobacteria were dominant throughout from early summer to late autumn in the lower Nakdong River (Ha 1999). The Microcystis aeruginosa is most commonly reported species of the genus Microcystis in the Nakdong River. Six species of the genus Microcystis; M. aeruginosa, $M$. viridis, $M$. wesenbergii, $M$. incerta, $M$. novacekii, $M$. ichthyoblabe have been identified in Nakdong River system (Lee et al. 1997). The maximum chlorophyll (chl) a concentration was $194 \mathrm{mg} \cdot \mathrm{m}^{-3}$ in 1992 and minimum was $43 \mathrm{mg} \cdot \mathrm{m}^{-3}$ in 2000 during the cyanobacterial waterbloom season, except that the frequent rainfall prevented algal waterblooms in 1993 (Fig. 3). The Microcystis aeruginosa was dominant from 1992 to 1998, but Aphanizomenon flos-aquae was temporarily dominant in 1999. Aphanizomenon flos-aquae was appeared in late September 1998 in Mulgum and the average chl a concentration and the standing crops were $59.5 \mathrm{mg} \cdot \mathrm{m}^{-3}$ and 150 cells $\cdot \mathrm{ml}^{-1}$, and were $202 \mathrm{mg} \cdot \mathrm{m}^{-3}$ and $0.5 \times 10^{3}$ cells $\cdot \mathrm{ml}^{-1}$ in July 1999. Lee et al. (2000) reported that the standing crops were lower than $2.4 \times 10^{4}$ cells $\cdot \mathrm{ml}^{-1}$ in July 1999, in July 2000 and August 2002 at the same point. In this study, the mean chl. a concentration ranged between $32.5 \mathrm{mg} \cdot \mathrm{m}^{-3}$ and $31.5 \mathrm{mg} \cdot \mathrm{m}^{-3}$ and the standing crops were between $0.9 \times 10^{3}$ cells $\cdot \mathrm{ml}^{-1}$ and $1.3 \times 10^{3}$ cells $\cdot \mathrm{m} l^{-1}$.

In the Hoedong Reservoir Aphanizomenon flos-aquae occurred in summer and winter. Unusually, Aphanizomenon

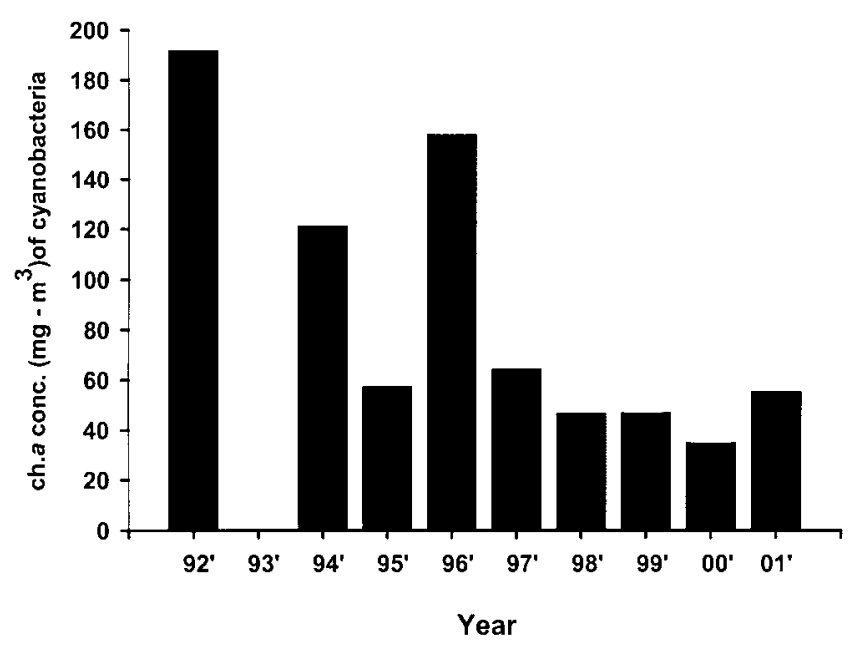

Fig. 3. Variations of average chlorophyll $a$ concentratin in Mulgum during cyanobacteria water bloom from 1992 to 2001.

bloom occurred January 2000 and cell density was $2.2 \times$ $10^{8}$ cells $\cdot \mathrm{m}^{-1}$. Though Microcystis aeruginosa occurred at the same time, over 95\% was dominated by Aphanizomenon flos-aquae that had the highest standing crops.

\section{Mouse bioassay}

A $1.0 \mathrm{ml}$ of STX were injected to all mice at concentrations of $0.1 \mathrm{mg} \cdot l^{-1}, 0.25 \mathrm{mg} \cdot l^{-1}, 0.5 \mathrm{mg} \cdot l^{-1}$ and $5.0 \mathrm{mg} \cdot l^{-1}$. At $0.1 \mathrm{mg} \cdot l^{-1}$ of STX, mice showed the symptoms of gasping breathing, tail rigor (after 1 minute) and lachrymation (after 17 minutes), and then recovered gradually and survived over 20 hours. Therefore, these were not neurotoxic response. At $0.25 \mathrm{mg} \cdot \mathrm{l}^{-1}$ of STX, mice had the symptoms of gasping breathing, salivation, diplegia (after 3 minutes), convulsion (after 9 minutes) and then died after 10 minutes. At $0.5 \mathrm{mg} \cdot l^{-1}$ of STX mice had the symptoms of sudden leaping movements, gasping breathing, mydriasis and convulsions and died after 3 minutes. At $5.0 \mathrm{mg} \cdot l^{-1}$ of STX, all mice died at once.

The mouse lethality of the cultured Aphanizomenon flos-aquae, evaluated by mouse bioassay, was 2.23 MU · mg dry cells ${ }^{-1}$ (Pereira et al. 2000). Mouse bioassays were performed with extracts of $A$. flos-aquae samples collected in January 2000 and July 1999, but showed no signs of toxicity. Mice had no response at the results of the injection with $0.25 \mathrm{~g}$ freeze-dried A. flos-aquae material, had symptoms of diplegia at $0.5 \mathrm{~g}$ after 5 minute but recovered gradually, and recovered after gasping breathing and mydriasis in 2 minutes at $1.0 \mathrm{~g}$. Therefore, $A$. flos-aquae materials were proved to be no neurotoxic response. 


\section{LC-MS analysis of ANTX-a and STX}

Chromatographic separation was obtained on a reversed phase column at $30^{\circ} \mathrm{C}$ under gradient conditions with a mobile phase of acetonitrile-water containing $0.1 \%$ TFA and a flow rate of $0.2 \mathrm{ml} \cdot \mathrm{min}^{-1}$. LC-MS analysis was implemented of $m / z 166$ for anatoxin-a concentration from 5.0 to $100 \mu \mathrm{g} \cdot l^{-1}, 5.56$ minutes of the retention time and correlation coefficient $\left(\mathrm{r}^{2}\right)$ higher than 0.999 as the result of analyzing ANTX-a standards.

There was no detection of ANTX-a toxin in cultured Anabaena flos-aquae NIER-10002 and cyanobacteria collected in Noksan (July 1997), Kangdong (1999) and Mulgum (1999), where cyanobacterial blooms were dominated by Microcystis aeruginosa and Anabaena flosaquae. The distilled water and filtered raw water collected in the Nakdong River were spiked with $3.0 \mu \mathrm{g} \cdot l^{-1}$ ANTX-a, respectively. As this result, ANTX-a toxin was detected at $2.9 \mu \mathrm{g} \cdot l^{-1}$ and $2.4 \mu \mathrm{g} \cdot l^{-1}$ and the recoveries were 96.7 and $78.3 \%$. This values were lower than 98.7$100 \%$ from Zotou and Jefferies (1999) but were similar to 80.5-97.6\% from Powell (1997). Bumke-Vogt et al. (1999) reported that the anatoxin content was $13.1 \mu \mathrm{g} \cdot l^{-1}$ from cyanobacteria Anabaena sp. and Aphanizomenon sp. in freshwater, and Himberg (1989) detected anatoxin (5 $\left.\mu \mathrm{g} \cdot \mathrm{l}^{-1}\right)$ from Anabaena flos-aquae.

ANTX-a has occurred occasionally in North America and northern Europe and no occurrence has been reported in Japan so far (Codd et al. 1994). Choi et al. (2002) reported that during summer in may 2000, ANTX-a was not detected in the lower Nakdong River where Anabaena flos-aquae was reported to occur massively with Microcystis aeruginosa. On the other hand, Park et al. (1998) reported that analyzed ANTX-a toxins from Korean reservoirs were maximum of $1,444 \mu \mathrm{g} \cdot l^{-1} \mathrm{dw}$.

The presence of paralytic shellfish poisonings (PSPs) in cyanobacteria has been proven in Aphanizomenon flosaquae (Alam et al. 1973; Mahmood and Carmichael 1986) and Lyngbya wollei from North America (Carmichael et al. 1997; Onodera et al. 1997), Anabaena circinalis from Australia (Humpage et al. 1994) and Cylindrospermopsis raciborskii from Brazil (Lagos et al. 1999). Under the analytical condition saxitoxin was detected at identical retention time of 5.80 minute by scanning respective protonated ions and similarity to the standard. STX toxins found in the cultured Aphanizomenon flos-aquae NIES-81 were further confirmed by LC-MS analysis. STX toxin from Aphanizomenon flos-aquae NIES-81 strain in the exponential growth phase (after culture 16 days) was detected for $0.45 \mu \mathrm{g} \cdot \mathrm{g}^{-1} \mathrm{dw}$. According to Pereira et al. (2000), neoSTX (23.0 $\mathrm{nmol} \cdot \mathrm{mg}^{-1}$ dry cells), dcSTX (6.1 $\mathrm{nmol} \cdot \mathrm{mg}^{-1}$ dry cells) and STX (5.4 nmol $\cdot \mathrm{mg}^{-1}$ dry cells) were detected from the cultured Aphanizomenon flosaquae in Motargil reservoir. Kaas and Henriksen (2000) showed that neoSTX $\left(0.9-6.5 \mu \mathrm{g} \cdot \mathrm{g}^{-1} \mathrm{dw}\right)$, dcSTX (0.8-7.0 $\left.\mu \mathrm{g} \cdot \mathrm{g}^{-1} \mathrm{dw}\right)$ and STX $\left(14.7-218 \mu \mathrm{g} \cdot \mathrm{g}^{-1} \mathrm{dw}\right)$ was detected from the cyanobacterial samples in Danish Lake. This content was higher than our result. It was reported that the detectable saxitoxin content from cyanobacteria Lyngbya wollei was $9-20 \mu \mathrm{g} \cdot \mathrm{g}^{-1} \mathrm{fw}$ and was higher than the toxin content from Anabaena flos-aquae and Aphanizomenon flos-aquae (Steffensen et al. 1994; Carmichael et al. 1997). STX toxin from the cultured Aphnizomenon flos-aquae were not detected that were extracted from the natural materials in the Nakdong River (July 1999) and Hoedong Reservoir (January 2000). In addition, the neurotoxic reaction was not considered in the mouse bioassay.

On the other hand, the microcystins from Aphanizomenon flos-aquae were detected in the Nakdong River and Hoedong Reservoir. In that station, microcystin-RR and -LR were detected for $37.4 \mu \mathrm{g} \cdot \mathrm{g}^{-1} \mathrm{dw}$ and $16.3 \mu \mathrm{g} \cdot \mathrm{g}^{-1} \mathrm{dw}$, respectively and in this station, for 24.9 $\mu \mathrm{g} \cdot \mathrm{g}^{-1} \mathrm{dw}$ and $6.6 \mu \mathrm{g} \cdot \mathrm{g}^{-1} \mathrm{dw}$ (data not shown). Though STX was reported to be produced by Aphnizomenon flosaquae, microcystins, one of the hepatotoxins were detected in it.

\section{REFERENCES}

Alam M., Ikawa M., Sasner J.J.Jr,. and Sawyer P.J. 1973. Purification of Aphanizomenon flos-aquae toxin and its chemical and physiological properties. Toxicon 11: 65-72.

AOAC. 1995. In official methods of analysis, 16th ed., vol. 2. Association of official analytical chemists, Arlington, Va. Method 959.08, Chapter 49, pp. 46-48.

Baker P.D. and Humpage A.R. 1994. Toxicity associated with commonly occurring cyanobacteria in surface waters of the Murray-Darling Basin. Aust. J. Mar. Freshwater Res. 45: 773786.

Bumke-Vogt C., Mailahn W. and Chorus I. 1999. Anatoxin-a and neurotoxic cyanobacteria in German lakes and reservoirs. John Willy \& Sons. Inc. pp. 117-125.

Carmichael W.W. 1992. Cyanobacteria secondary metabolitesthe cyanotoxins. J. Appl. Bacteriol. 72: 445-459.

Carmichael W.W., Evans W.R., Yin Q.Q., Bell P. and Moczydlowski E. 1997. Evidence for paralytic shellfish poisons in the freshwater cyanobacterium Lyngbya wollei (Farlow ex Gomont) comb. nov. Appl. Environ. Microbiol. 63: 3104-3110. 
Choi A.R., Park J.H. and Lee J.A. 2002. Population dynamics and the toxin of Anabaena in the lower Naktong river. Algae 17: $95-104$

Codd G.A., Jefferies T.M., Keevil C.W. and Potter E. 1994. Detection methods for cyanobacterial toxins. Cambridge, UK. pp. 25-33.

Falconer I.R. 1993. Mechanism of toxicity of cyclic peptide toxins from blue-green algae. In: Falconer I.R. (ed.), Algal toxins in seafood and drinking water. Academic Press. San Diego. pp. 176-186.

Falconer I.R. 1999. An overview of problems caused by toxic blue-green algae (cyanobacteria) in drinking and recreational water. Environ. Toxicol. 14: 5-12.

Ha K. 1999. Phytoplankton community dynamics and Microcystis bloom development in a hypertrophic river (Nakdong River, Korea). Ph. D. dissertation. Pusan National University, 140 pp.

Harada K.I., Ohtani I., Iwamoto K., Suzuki M., Watanabe M.F., Watanabe M. and Terao K. 1994. Isolation of cylindrosperrmopsin from a cyanobacterium Umezakia natans and its screening method. Toxicon 32: 73-84.

Himberg K. 1989. Determination of anatoxin-a, the neurotoxin of Anabaena flos-aquae cyanobacyerium, in algae and water by gas chromatography-mass spectrometry. J. Chromatography 481: 358-362.

Humpage A.R., Rositano J., Bretag A., Brown R., Baker P., Nicholson B.C. and Steffensen. D.A. 1994. Paralytic shellfish poisons from Australian cyanobacterial blooms. Aust. J. Mar. freshwater Res. 45: 761-771.

Ikawa M., Wegener K., Foxall T. L. and Sasner J.J.Jr. 1982. Comparison of the toxins of the blue-green alga Aphanizomenon flos-aquae with the Gonyaulax toxins. Toxicon 20: 747-752.

Jaime E., Hummert C., Hess P. and Luckas B. 2001. Determination of paralytic shellfish poisoning toxins by high-performance ion-exchange chromatography. $J$. Chromatography A 929: 43-49.

Kaas H. and Henriksen P. 2000. Saxitoxin (psp toxins) in Danish Lakes. Wat. Res. 34: 2089-2097.

Lagos N., Onodera H., Zagatto P.A., Andrinolo D., Azevedo S.M.F.Q. and Oshima Y. 1999. The first evidence of paralytic shellfish toxins in the freshwater cyanobacterium Cylindrospermopsis raciborskii, isolated from Brazil. Toxicon 37: 1359-1373.

Lee J.A., Choi A.R. and Watanabe M. 1997. Toxonomic implication of the genus Microcystis (cyanophyceae) from the
Naktong River. Algae 12: 167-176.

Mahmood N.A. and Carmichael W.W. 1986. Paralytic shellfish poisons produced by the freshwater cyanobacterium Aphanizomenon flos-aquae NH-5. Toxicon 24: 175-186.

Namera A., So A. and Pawliszyn J. 2002. Analysis of anatoxin-a in aqueous samples by solid-phase microextraction coupled to high-performance liquid chromatography with fluorescence detection and on-fiber derivatization. J. Chromatography A 963: 295-302.

Ohsima Y. 1995. Post-column derivatization HPLC methods for paralytic shellfish poisons. In: Hallegraeff G.M., Anderson D.M. and Cembella A.D.(eds), Manual on harmful marine microalgae. IOC manuals and guides No. 33. UNESCO. pp. 81-94.

Onodera H., Satake M., Oshima Y., Yasumoto T. and Carmichael W.W. 1997. New saxitoxin analogues from the freshwater filamentous cyanobacterium Lyngbya wollei. Nat. Toxins 5: 146-151.

Park H.D., Kim B., Kim E. and Okino T. 1998. Hepatotoxic microcystins and neurotoxic anatoxin-a in cyanobacterial blooms from Korean Lakes. Environ. Toxicol. Water Qual. 13: 225-234.

Pereira P., Onodera P.H., Andrinolo D., Franca S., Araujo F., Lagos N. and Oshima Y. 2000. Paralytic shellfish toxins in the freshwater cyanobacterium Aphanizomenon flosaquae, isolated from Montargil reservoir, Portugal. Toxicon 38: $1689-702$.

Powell M.W. 1997. Analysis of anatoxin-a in aqueous samples. Chromatographia 45: 25-28.

Sivonen K. and Jones G. 1999. Cyanobacterial toxins. In: Chorous I. and Bartram J. (eds). Toxic cyanobacteria in water. EFN Spon., London. pp. 41-111.

Steffensen D.A., Humpage A. R., Rositano J., Bretag A.H., Brown R., Baker P.D. and Nicholson B.C. 1994. Neurotoxin from Australian Anabaena. In: Codd G.A., Jefferis T.M., Keevil C.W. and Potter E. (eds), Detection methods for cyanobacterial toxins. RSC., pp. 45-50.

Wetzel R.G. and Likens G.E. 1991. Limnological analysis. 2nd ed. Springer-Verlag. New York. 391 pp.

Zotou A. and Jefferies T.M. 1999. Determination of anatoxin-a and homoanatoxin in blue-green algal extracts by highperformance liquid chromatography and gas chromatography-mass spectrometry. Analyst. 118: 753-758.

Received 25 July 2003

Accepted 8 September 2003 